Magdalena Zych

Muzeum Etnograficzne im. Seweryna Udzieli w Krakowie

\title{
Rzucanie światłem
}

W czasie akcji „Rzućmy światło na Muzeum”, przygotowanej przez Stowarzyszenie FestivALT (kuratorki: Erica Lehrer, Lena Rubenfeld-Koralewska), prezentowanej między 15 a 18 grudnia 2020 roku na fasadzie kazimierskiego Ratusza, siedzibie Muzeum Etnograficznego w Krakowie, nachodziły mnie rozmaite refleksje, zwłaszcza o tym, jakim wyzwaniem jest współpraca. Zanim się nimi podzielę, chciałabym odnieść się do relacji między muzeum a stowarzyszeniem, do materiałów prasowych akcji i przekazu kuratorek. Nakreślę również kontekst wydarzenia oglądanego z perspektywy muzeum.

1.

Doświadczenia kontaktów MEK z aktywistami działającymi pod szyldem FestivALT-u mają już swoją historię i sięgają początków działalności organizacji, czyli 2017 roku¹. Intensyfikacja współpracy przypadła na 2019 rok. W czasie wystawy „Widok zza bliska. Inne obrazy Zagłady”, której byłam kuratorką razem z Eriką Lehrer, Romą Sendyką i Wojciechem Wilczykiem (sama wystawa była rezultatem 3-letnich badań tego zespołu na temat obecności wątku Zagłady w sztuce ludowej; prezentowana była w MEK od 1 grudnia 2018 do 31 kwietnia 2019²) miało miejsce wspólnie zorganizowane oprowadzanie kuratorskie dla osób związanych ze stowarzyszeniem,

\footnotetext{
${ }^{1}$ Zob. Fotoesej Jasona Francisco zamieszczony w tomie: Różnicowanie narodowego „my”: Kuratorskie marzenia, red. R. Sendyka. E. Lehrer, Wydawnictwo Uniwersytetu Jagiellońskiego, Kraków 2019, s. 124-132.

${ }^{2}$ Więcej na stronie omawiającej wystawę: www.widokzzabliska.eu, dostęp 1.07.2021 r.
} 
a kilka miesięcy później, 26 czerwca 2019 roku, dyskusja o recepcji wystawy stałej MEK z publicznością zaproszoną przez FestivALT, w której wzięłam udział razem z dyrektorem MEK dr. Antonim Bartoszem³ ${ }^{3}$.

Wskutek tej ciekawej i pełnej emocji rozmowy, na wystawie stałej w miejscu prezentacji masek postaci Żydów z żywieckich grup kolędniczych ${ }^{4}$ pojawił się mój komentarz, który w całości przytoczę, a prezentacja masek została zastąpiona prezentacją ich fotografii. Nawiązałam w nim i do dyskusji (o której wspominają też kuratorki akcji „Rzućmy światło na Muzeum”), i do moich osobistych refleksji związanych z wykonywaną w muzeum codzienną pracą.

Podczas przywołanej wyżej dyskusji w czerwcu 2019 roku okazało się, że prezentowana wcześniej w tym miejscu informacja o stereotypach nie była przez część zwiedzających zauważana, oddziaływanie samych eksponatów wymagało dopowiedzenia wprost kontekstu ich funkcjonowania, dlatego dyrektor MEK podjął decyzję o zmianach. Wraz ze mną nad ostatecznym kształtem tej części ekspozycji pracował zespół kuratorski ${ }^{5}$.

\section{„[Kim jesteś, masko?]}

Nie dają mi spokoju maski Żydów i Cyganów z różnych grup kolędniczych. Nieraz słyszałam pytania, dlaczego pokazujemy takie karykatury? Co z uczu-

\footnotetext{
${ }^{3}$ Każde muzeum jest opowieścią: rozmowa z dyrektorem MEK. Z anonsu: „FestivALT zapraszamy na rozmowę z dyrektorem Antonim Bartoszem o wystawie stałej i kolekcji Muzeum. Wspólnie zastanowimy się, jaką opowieść powinno budować Muzeum, by każdy mógł się w niej odnaleźć. Jak sprawić, by reprezentowała wielość kultur i ich dziedzictwa, złożoność i różnorodność postaw, wielowątkowość życia? Co zrobić, żeby Żydzi także mogli powiedzieć »Moje muzeum, muzeum o mnie«? W tym dniu zwiedzanie wstęp na wystawę główną jest darmowy na hasło FestivALT”.

${ }^{4}$ Ostatnia dokumentacja terenowa działań żywieckich grup kolędniczych została zrealizowana w ramach projektu badawczego MEK „Życzenia” podczas przeglądu w Milówce w styczniu 2019 roku. Jej autorką jest kustoszka Karolina Pachla-Wojciechowska (kierująca projektem), autorem zdjęć Marcin Wąsik.

${ }^{5}$ Ten sam, który stworzył scenariusz najnowszej części wystawy stałej pt. „Kogo stać?”. Opowiada ona o realiach życia na wsi w pierwszych dekadach XX wieku zróżnicowanymi etnicznie głosami. Zespół kuratorski: Olga Błaszczyńska, Dorota Majkowska-Szajer — kierująca pracami, Agnieszka Marczak, Małgorzata Oleszkiewicz, Karolina Pachla-Wojciechowska, Katarzyna Piszczkiewicz, Urszula Sobczyk, Magdalena Zych. Prace nad scenariuszem rozpoczęły się w 2018 roku. Teksty na wystawie pochodzą ze współczesnych badań MEK oraz ze źródeł: Pamiętniki chłopów, przedmowa Ludwik Krzywicki, Instytut Gospodarstwa Społecznego, Warszawa 1935; Ostatnie pokolenie. Autobiografie polskiej młodzieży żydowskiej okresu międzywojennego ze zbiorów YIVO Institut for Jewish Research $w$ Nowym Jorku, opracowanie i wstęp Alina Cała, teksty napisane w jidysz przełożył Michał Friedmann, Warszawa 2003 oraz Feliks Gross, Zygmunt Mysłakowski, Robotnicy piszą. Pamiętniki robotników, studium wstępne, Księgarnia Powszechna, Kraków 1938. Wystawa gotowa była już w grudniu 2020, udostępniona publiczności od stycznia 2021 po zniesieniu ograniczeń związanych z pandemią.
} 
ciami Romów i Żydów odwiedzających muzeum, którzy stając przed nimi, zadają sobie pytanie: czy to jest moje muzeum, muzeum o mnie?

Skąd się wzią Żyd wśród kolędników? Czy z czasów, gdy starsze, przedchrześcijańskie kolędowanie połączyło się z kościelnym teatrem obrzędowym? Którędy weszli do kanonu grup kolędniczych Żyd Rabin (wśród kolędujących z królem Herodem) i Żyd Handlarz (wśród kolędujących z turoniem)? Może to daleki ślad komedii dell'arte, echo postaci Pantalona (weneckiego kupca) i Służących? A może powód jest zupetnie inny?

Faktem jest, że do dziś przeglądy $i$ konkursy dla rozmaitych grup kolędniczych utrwalają karykaturalne przedstawienia postaci Żyda i Cygana. Tradycja ta jest uświęcana na różne sposoby. Na przykład poprzez odbywający się od 1969 roku przegląd żywieckich grup kolędniczych „Żywieckie Gody”, kultywujący tradycję Dziadów żywieckich, wpisaną na Krajową Listę Dziedzictwa Niematerialnego UNESCO w 2016 roku.

Z Zabłocia, dziś części Żywca, wywodza się Jukace, jedna z odmian żywieckich Dziadów, to tam chodziły przybywające z okolicy „bandy” przebranych młodzieńców, świszczac batem. Zwyczaj traci na niewinności, jeśli przyjrzeć się bliżej lokalnym konfliktom. W 1937 roku na Zabłociu, gdzie mieszkali Żydzi (nie wolno im było osiedlać się $w$ Żywcu), doszło do tumultu antyżydowskiego, $w 1935$ roku rozwieszano tam antysemickie plakaty, a zamieszki wybuchałyjuż w 1933 roku. W 1925 w „Gazecie Żywieckiej” pojawiał się apel o omijanie żydowskich sklepów. W 1918 roku szkody spowodowane Żydom w okolicznych wsiach wyniosły sto tysięcy koron. Tak było w wielu miejscach $w$ przedwojennej Polsce. Antysemityzm przedostawał się w różne rejony życia, także do folkloru. I znalazł w nim swoje miejsce.

$W$ czasie II wojny światowej $w$ Europie i $w$ Polsce miała miejsce masowa i zaplanowana przez hitlerowskie Niemcy eksterminacja Romów i Żydów. Nieliczni, którzy ocaleli, po wojnie wyjechali lub wtopili się w etniczna większość. Niemal wszyscy Żydzi z żywieckiego Zabłocia zginęli w Auschwitz.

Widoczne w maskach odhumanizowanie i szyderstwo jest pierwszym krokiem w przesuwaniu granic przyzwolenia na przemoc wobec tych, którzy żyja inaczej. Konwencja przedstawiania Żydów i Cyganów ujawnia destrukcyjna moc stereotypów wyrażonych $w$ działaniu nadal wspieranym przez ekspertów.

Czy ta tradycja naprawdę jest niewinna?”

Pierwszy raz nową aranżację ekspozycji masek kolędniczych zaprezentowaliśmy publiczności w czasie wspólnych, przeprowadzonych przez MEK i FestivaALT warsztatów dla uczestników konferencji „What’s new? Revisiting 
New Museology 30 years later” 20-21 listopada 2019 roku, zorganizowanej przez Muzeum Narodowe w Krakowie, Instytut Historii Sztuki UJ i Instytut Etnologii i Antropologii Kulturowej UJ. W tekście kuratorskim akcji „Rzućmy światło na Muzeum” przytoczony wyżej komentarz nazwano „samokrytycznym”. Nie tworzyłam go jako samokrytyki. Napisałam go, bo uważam, że nadszedł czas na zmiany w interpretacji zjawisk kulturowych, a osoby, z którymi współpracuję tworząc MEK podzielają taką perspektywę.

Wcześniej, w roku akademickim 2016/2017 grupa studentek seminarium dr hab. Romy Sendyki, szefującej Ośrodkowi Badań nad Kulturami Pamięci działającemu przy Wydziale Polonistyki UJ, przygotowała w MEK jednodniowe wydarzenie komentujące elementy i części wystawy stałej, którego prezentacja ujęta była w program FestivALTu w 2017 roku' . Z grupą oprócz prowadzącej zajęcia i mnie współpracowała także dr Erica Lehrer i dr Marek Tuszewicki z Instytutu Judaistyki UJ. Wydarzenie odbyło się miesiąc po Nocy Muzeów, której program pod szyldem „Muzea i kontrowersje” pozwolił kuratorkom MEK Dorocie Majkowskiej-Szajer i Katarzynie Piszczkiewicz odnieść się krytycznie do wybranych elementów wystawy stałej (w wielu miejscach pojawiły się ich komentarze uwrażliwiające publiczność na trudne i nieobecne tematy). Część tych elementów uległa przeobrażeniu w związku z prezentacją nowej części wystawy stałej w 2020 roku (czyli ekspozycji pt. „Kogo stać?”). Warto przypomnieć, że jednym z efektów otwartej przed dekadą (w 2011 roku) innej części wystawy stałej pt. „Od-nowa” jest rezygnacja z prezentowania jako elementu ekspozycji kopii fotografii przedstawiającej palenie kukły Judasza w Pruchniku. Przytoczone przykłady przypominają, że niestałość wystawy stałej jest jej ważną cechą.

Powyższe działania pracowniczek MEK, dyrektora, historia współpracy ze środowiskiem związanym ze Stowarzyszeniem FestivALT moim zdaniem przekonująco dowodzą istnienia wspólnego kierunku refleksji na temat tego, jak ulepszać i zmieniać muzealną narrację na temat wykluczeń i nierówności związanych z tematami etnicznymi, religijnymi, klasowymi, ekonomicznymi.

Tymczasem akcja „Rzućmy światło na Muzeum” w mojej opinii jest działaniem instrumentalnie traktującym zmieniającą się i otwartą na współpracę instytucję.

\footnotetext{
${ }^{6}$ Studenckie wydarzenie miało miejsce 27 czerwca 2017 roku. Owocem tej współpracy jest publikacja przywołana już w pierwszym przypisie Różnicowanie narodowego „my”: Kuratorskie marzenia. Zamieszczony w niej mój tekst pt. Muzeum etnograficzne, o jakim marzę, jest miejscem wspólnym komentuje kontekst, w jakim funkcjonuje MEK i jego krytyka.
} 


\section{2.}

W materiałach prasowych prezentujących akcję Stowarzyszenie deklarowało, iż „kluczowym elementem projektu jest partnerstwo Muzeum Etnograficznego w Krakowie, które poddając się autokrytyce, w pionierski na skalę Polski sposób, pokazuje swoją gotowość do zmierzenia się z tym trudnym tematem [chodzi o wpływ muzeów na kształtowanie świadomości odbiorców] oraz ze swoim dziedzictwem”. Odnosząc się do tego fragmentu akcję stowarzyszenia nazwałabym krytyką a nie autokrytyką gdyż to nie muzeum przygotowało ów projekt, stało się jedynie miejscem akcji. Sformułowana w ramach akcji „Rzućmy światło na Muzeum” krytyka pokazuje, że instytucja wzbudza zainteresowanie, emocje, oczekiwania — rezonans działań muzealnych jest zawsze czymś pozytywnym. Krytyka, która ma na celu zmianę, jest wartościowym elementem dialogu, o ile odbywa się na zasadach umożliwiających rozmowę, w której obie strony mogą razem wybrzmieć. Nie był to ten przypadek.

Pragnę także zauważyć, że akcja stowarzyszenia nie jest pionierska, gdyż muzeum na wiele sposobów pokazywało w poprzednich latach gotowość do mierzenia się z tematem wpływu muzeów na kształtowanie świadomości odbiorców a także otwartość na konfrontację ze swoim dziedzictwem. Przykładem są chociażby wcześniejsze kontakty ze stowarzyszeniem oraz inicjowane przez MEK działania: wystawy (w tym wiele wystaw zorganizowanych w partnerstwie z Festiwalem Kultury Żydowskiej, Miesiącem Fotografii), badania, kooperacje, wydarzenia.

Ponadto, czy sprowadzanie działalności muzeum do wystawy stałej jest wobec instytucji uczciwe? Czy wówczas nie należałoby mówić nie o muzeum jako całości lecz po prostu o głównej wystawie muzeum? Co z innymi muzeami, w tym etnograficznymi?

Na potrzeby przygotowywanych wypowiedzi artystów zaproszonych do projektu przez Stowarzyszenie FestivALT, dyrektor udostępnił kuratorkom dokumentację fotograficzną wystawy stałej, chcąc umożliwić w tych trudnych warunkach rozwój tworzonych projektów (ustalenia, że w 2020 roku działanie artystów pojawi się w przestrzeni MEK strony podjęły jeszcze przed pandemicznymi ograniczeniami). Pozostawił twórcom wolną rękę, nie ingerując w przekaz. Artyści nie mieli możliwości by zapoznać się osobiście z aktualnymi wystawami lub kolekcją. Byli, podobnie jak inni odbiorcy, zdani na internetową aktywność muzeum (w tym kontekstową prezentację kolekcji MEK w ramach wieloletniego cyklu „Obiekt 
tygodnia”), i swoje wcześniejsze doświadczenia. Przygotowanym w takich okolicznościach pracom Doroty Mytych, Jacqueline Nicholls, Wiktora Podgórskiego, wyświetlanym w grudniowe wieczory na ścianach Ratusza, czy widocznym przez otwarte okno, towarzyszył tekst kuratorski autorstwa Eriki Lehrer i Leny Rubenfeld-Koralewskiej. Autorki m.in. cytowały w nim wypowiedzi z przywołanego już wcześniej (2019) spotkania o wystawie stałej MEK, były to wypowiedzi osób prowadzących spotkanie, dyrektora MEK i głosy publiczności.

\section{3.}

We wstępie znajdziemy uzasadnienie dla akcji: według kuratorek jest ona „próbą wykorzystania tego trudnego momentu [pandemii] do odzyskania naszych muzeów i wspólnego przemyślenia ich funkcjonowania. Do uwzględnienia głosu wszystkich nas, których działalność muzeum dotyczy”. Z tego fragmentu i innych podobnych można wywnioskować, iż autorkom nie chodzi o wystawę stałą MEK, lecz o funkcjonowanie muzeów w ogóle. Intryguje mnie sformułowanie „wszystkich nas”. W czyim imieniu mówią autorki? Czy w imieniu wszystkich zwiedzających i członków wszystkich społeczności? Wcześniej kuratorki piszą, iż z powodu pandemii ujawniającej nierówności i wyostrzającej konflikty, muzea zostały zmuszone „do uznania swojego udziału w niesprawiedliwym porządku świata”. Jak się ma ta uwaga do akcji „Rzućmy światło na Muzeum”?

W dalszej części tekstu autorki koncepcji kuratorskiej skupiają się na wystawie stałej MEK. Pojawia się zarzut: „żydowska historia ani kultura, choć była integralną częścią historii polskiej wsi i miasteczek, nie jest częścią wystawy stałej MEK, a Żydzi są przedstawiani (często negatywnie) jedynie z perspektywy swoich katolickich sąsiadów”. Odnosząc się do tego fragmentu pragnę podkreślić, że prezentowana w MEK wystawa stała jest narracją opowiadającą głównie o rolniczym i pasterskim świecie małopolskich wsi z przełomu XIX i XX wieku (na ten czas datowane są prezentowane eksponaty), i w tym okresie większość mieszkańców wsi stanowili chłopi chrześcijańskich wyznań różnych obrządków. W zbiorach są przedmioty, z którymi równie dobrze identyfikowaliby się ludzie określani jako chłopi-Polacy, chłopi-Ukraińcy, chłopi-Łemkowie, chłopi-Bojkowie i chłopi-Żydzi, a z niektórymi także wędrujące grupy Romów. Identyfikacja narodowa w tej klasie społecznej dopiero się wówczas tworzyła. Rolnicy, pasterze i rzemieślnicy nie są na wystawie pokazywani w perspektywie ich pocho- 
dzenia etnicznego tylko przez pryzmat wykonywanych zajęć. Świat sztetla nie jest tematem tej wystawy, o czym oczywiście można i warto dyskutować. Co równie ważne, wystawę tworzą warstwy pochodzące z siedmiu dekad działania muzeum w tej siedzibie (po nacjonalizacji i od $1945 \mathrm{roku}$ ), wraz z całym historycznym bagażem wartym omówienia w innym miejscu. Przed ostatnią modyfikacją fragmentu wystawy stałej także były na niej miejsca, w których pojawiała się reprezentacja romskiej, bojkowskiej, ukraińskiej czy żydowskiej obecności. Na pewno powinniśmy pytać czy wystarczająca (moja odpowiedź brzmiałaby, że zdecydowanie nie) jednak faktem jest, że wystawa stała obejmowała i obejmuje zróżnicowanie etniczne. Obecna na niej prezentacja obiektów związanych z utrwalonymi w folklorze postaciami Żydów była przez muzeum skomentowana w 2017 roku, a potem gruntownie zmodyfikowana w roku 2019 (o czym pisałam wyżej i do czego odwołują się kuratorki wydarzenia).

Tymczasem tekst kuratorski zbudowany na nieautoryzowanych cytatach pozostawia wrażenie, iż zarzuty budowania przez wystawę stałą antysemickiej narracji, potwierdzone $\mathrm{w}$ rozmowie $\mathrm{z}$ przedstawicielami MEK, pozostały od czerwca 2019 roku właściwie bez echa, poza zmianą w miejscu prezentacji masek. Wypowiedzi dyrektora, objaśniające kontekst funkcjonowania instytucji (trudności z pozyskaniem środków na zmianę wystawy stałej), zestawione zostały z zarzutem o to, iż nadal MEK prezentuje „prześmiewcze żydowskie figurki stworzone przez chrześcijańskich rzemieślników, prezentowane są jako śmieszne zabawki” [chodzi o figurki przedstawiające postaci Żydów kupowane na emausowym odpuście czyli święcie lokalnej parafii w l. 20. XX wieku wraz z innymi stereotypowi figurkami traktowanymi wówczas jako zabawki; nie wiemy jakiego wyznania byli ich twórcy - MZ] a „kolekcja zawiera także karykaturalne żydowskie stroje [chodzi o pojedyncze przykłady ubiorów postaci z grup kolędniczych - MZ], ule w kształcie Żydów [dwa ule figuralne mające charakter apotropeiczny, podobnie jak ul w kształcie niedźwiedzia-MZ], małe drewniane lalki przedstawiające więźniów z Auschwitz [chodzi o rzeźby Franciszka Skocza z Bochotnicy (1908-2000), rzeźbiarza więzionego w obozie Auschwitz oraz Neuengamme w Hamburgu, nie wiemy jednak czy praca „Obóz” z 1978 roku przedstawia Żydów - MZ7), a także zdjęcie z wizerunkiem Judasza z wielkim czerwonym nosem, zawieszonego na pętli

\footnotetext{
${ }^{7}$ Więcej na temat kontekstu rzeźb zob.: http://www.widokzzabliska.eu/wystawa/franciszekskocz-oboz
} 
na drzewie [chodzi o fotografię z 1953 roku z Pruchnika prezentowaną od 1. 90 XX wieku na wystawie stałej do 2011 r., o czym wspominałam wyżej, a na temat kontekstu zjawiska obszernie pisała judaistka i archiwistka z MEK Kamila Wasilewska-Prędki w ramach cyklu „Obiekt tygodnia” MZ]”. Zaraz po przytoczonych przykładach tego, co jest w kolekcji MEK kuratorki piszą:

Po naszej publicznej rozmowie w ramach FestivALT-u w 2019 roku, MEK zmienił sposób prezentacji antyżydowskich masek. Obiekty zostały zastąpione przez fotografie oraz samokrytyczny komentarz na temat odpowiedzialności muzeum w stosunku do jego żydowskiej i romskiej publiczności. Skoro jedne interwencje są możliwe... czemu nie inne?

Chciałabym zatem zapytać, co poza krytyką umiejscowienia w kolekcji (ale nie prezentowanych na wystawie) określonych obiektów lub krytyki braków, aktywiści proponują? To, że na wystawie stałej prezentowane są fotografie postaci Żydów z grup kolędniczych a nie ich maski nie zmienia faktu, że stereotyp Żyda jest nadal obecny w polskiej, i nie tylko w polskiej, kulturze, podobnie jak antysemityzm ${ }^{9}$. W zbiorach MEK oprócz wymienionych przez kuratorki przedmiotów są i inne: tefilin Żydów Bucharskich ${ }^{10}$, napierśniki, fotografie przedstawiających różnych ludzi: rabinów z Bełza Aarona Rokeacha i Izaaka Herzoga ${ }^{11}$, anonimowych XIX-wiecznych kupców z Podola ${ }^{12}$, jest malowanka Sławomira Kosiniaka z Zalipia datowana na koniec lat $40 \mathrm{XX}$ w. prezentująca wyłapywanie żydowskiej rodziny przez granatową policję ${ }^{13}$, są rzeźby Adama Zegadły przedstawiające Żydów, a ta zatytułowana „Wesele żydowskie” jest prezentowana na wystawie stałej, jak również przejmująca płaskorzeźba Władysława Chajca pt. „Krematorjum”, i wiele innych. W kolekcji MEK jest wiele materiału, który obrazuje relacje polsko-żydowskie. To na przykład fotografie z anonimowego źródła przedstawiające podział mienia żydowskiego między oczekujące chłopskie furmanki na rynku w Wielopolu Skrzyńskim.

\footnotetext{
${ }^{8}$ Zob. https://etnomuzeum.eu/zbiory/obchod-judasza-w-przeworsku

${ }^{9}$ Precyzyjnie temat naświetla Bożena Keff w tekście Żyd stosowany z 18 września 2018 opublikowanym na łamach „Krytyki Politycznej”, https://krytykapolityczna.pl/kultura/zydstosowany-polska-esej-bozeny-keff oraz wiele autorek i autorów analizujących zjawisko antysemityzmu w polskiej kulturze w perspektywie antropologicznej (Ludwig Stomma, Alina Cała, Joanna Tokarska-Bakir i inni).

${ }^{10} \mathrm{https}$ ://etnomuzeum.eu/zbiory/tefilin-zydow-bucharskich

${ }^{11} \mathrm{https}$ ://etnomuzeum.eu/zbiory/rabin-z-belza

${ }^{12} \mathrm{https}$ ://etnomuzeum.eu/kolekcje/fotografie-michala-greima

${ }^{13}$ https://etnomuzeum.eu/zbiory/sceny-zajmujace-malowanka-z-zalipia
} 
W kolekcjach wszystkich muzeów etnograficznych znajdziemy mnóstwo ciekawych i często trudnych w opracowaniu przedmiotów, które stanowią wspaniałe pole interpretacji, mogą otwierać dialog i zwiększać empatię różnych grup odbiorców. Nie interesują jednak krytyków wybiórczo potraktowanej oferty muzealnej na tyle, by poświęcić im uwagę, zaproponować dla nich nowe odczytania, włączyć ponownie w obieg. Jak do tej pory, w czteroletniej historii kontaktów z muzeum, aktywiści Stowarzyszenia FestivALT nie sięgnęli do etnograficznej kolekcji MEK, nie skierowali się również w stronę jej źródeł. W materiałach zaproponowanych przez artystów znalazło się miejsce na refleksję, pytania i próby spojrzenia na kolekcję. Nie można tego jednak powiedzieć o kuratorskim opisie.

4.

Jak wyglądało życie w krakowskim Muzeum Etnograficznym w grudniu 2020 roku? Tak, jak pozwalały na to warunki. Wiele kontaktów z odbiorcami muzealnych działań odbywało się w trybie zdalnym. 15 grudnia, w dniu transmitowanego na Facebooku wernisażu akcji „Rzućmy światło na Muzeum” w którym wzięłam udział, kilka godzin wcześniej miało miejsce spotkanie on-line rozwijające wątek selkupskich figurek kultowych z kolekcji MEK, pt. „Las duchów”"14, równolegle figurki te prezentowano na wystawie „Syberia. Głosy z Północy”, wówczas jednak zamkniętej dla publiczności. W tym samym czasie przygotowywano warsztaty dla najmłodszych związane ze świętem Chanuki (nie tylko FestivALT nawiązywał do tego święta, samo muzeum także), miały się odbyć zdalnie. W grudniu zwiedzający nie mogli korzystać z udostępnionej w czasie pandemii miejskiej gry terenowej „Kazimierz od podszewki” autorstwa Urszuli Sobczyk, prezentującej fotografie ze zbiorów MEK w kontekście historii sąsiedztwa muzeum, tym niemniej wkrótce można było do tego powrócić (gra stała się częścią programu tegorocznej edycji cyklu Synagogi Nocą, partnerem wydarzenia były: Centrum Społeczności Żydowskiej w Krakowie JCC, Instytut Judaistyki UJ, Muzeum Krakowa Oddział Stara Synagoga). Dopiero co skończono prace nad wspomnianą nową częścią wystawy stałej pt. „Kogo stać?”. Trwały codzienne działania związane z opracowaniem zbiorów i troską o ich kondycję, pracownicy i pracowniczki MEK rotacyjnie pojawiali się w magazynach i biurach, wiele prac toczyło się w prywatnych wnętrzach ich domów.

\footnotetext{
${ }^{14}$ Spotkanie można odtworzyć na kanale MEK w serwisie You Tube.
} 
Akcja „Rzućmy światło na Muzeum” w moim odczuciu zbudowana została głównie jako komunikacja dla publiczności zagranicznej. Wernisaż odbywał się w języku angielskim, ostatni cytowany w tekście kuratorskim głos publiczności nawiązuje do życia w Holandii i tego, że muzeum nie zauważa swego własnego antysemityzmu; część funduszy na akcję pochodziła ze środków holenderskiej fundacji Dutch Jewish Humanitarian Aid, pozostali darczyńcy to Fundacja Allianz niemieckiej firmy ubezpieczeniowej, Concordia University z Kanady, Ministerstwo Spraw Zagranicznych RP. Po akcji pozostał interesujący wizualnie ślad w postaci raportów dla sponsorów i materiału na konferencje. Omawiane wydarzenie niewiele miało wspólnego z lokalną i realizowaną z szacunkiem drogą współpracy. Sam termin „interwencja”, a więc „wywieranie na kogoś wpływu w celu uzyskania efektu” jest słowem z porządku presji, nacisku, ustanawiającym hierarchię. W tym przypadku w sposób wręcz kolonialny oświeca to, co w domyślnym założeniu pozostaje w ciemności, a więc lokalne muzealne praktyki.

Kuratorki przedsięwzięcia tworząc działanie krytykujące instytucję poprzez jej zmieniającą się przecież wystawę stałą, nie proponują konstruktywnych zmian i nie dostrzegają pracy skupionej na polsko-żydowskich relacjach czy współpracy z innymi instytucjami czy środowiskami. Wytykając sam fakt istnienia w zbiorach przykładów antysemityzmu w folklorze kuratorki nie uwzględniają tego, że jest to sytuacja, w której istniejące zjawisko ma odbicie w kolekcji, oraz w historii jej prezentacji. Pomijają też fakt, iż pracujące w muzeum osoby są świadome problemu i w miarę możliwości dążą do zmiany komunikatu, jaki płynie z wystawy stałej. Dyscyplinowanie instytucji służy budowaniu autorytetu. Akcja stowarzyszenia została przygotowana jako efektowny wizualnie pokaz, a jego rejestracja jako narzędzie prezentujące skuteczność działania organizacji. W tym kontekście instrumentalne potraktowanie kilku lat wspólnej, opisanej wyżej współpracy powoduje, że w moim odczuciu zaufanie budujące dialog zostało nadszarpnięte. Wypowiedź kuratorska towarzysząca prezentacjom została odebrana przez zespół muzeum jako nastawione na konflikt oskarżanie o zaniechania, szerzenie antysemickich stereotypów i paternalistyczne „oświecanie” tworzących muzeum osób.

Czy interwencja zwiększyła widzialność w głównym obiegu marginalizowanych dotychczas problemów? Czy ułatwiła refleksję nad pojawieniem się tematu antysemityzmu w interpretacji kolekcji etnograficznych? Czy uwrażliwiła na problemy i wpłynęła na zwiększenie empatii wśród od- 
biorców? Czy umożliwiła akceptację trudnych doświadczeń osobom, do których przekaz był skierowany? Czy posłużyła zwiększeniu transparentności w działaniach instytucji (muzeum, stowarzyszenia)? Czy włączając głosy spoza muzeum nie dążyła do uciszenia głosów osób to muzeum tworzących? Czy interwencja była działaniem dekolonizującym czy wręcz przeciwnie, kolonizowała? Czy dzielenie się przez instytucję autorytetem ma prowadzić do wytworzenia nowego ${ }^{15}$.

W grudniowym, szybko zapadającym zmroku w tej części Europy ciemność zatapia wszystko. Dlatego tęsknota za światłem jest widoczna w wielu praktykach związanych z czasem zimowego przesilenia, oczywiście także w pomyśle na interwencję FestivALT-u na fasadzie muzeum. Efekt utknięcia w ciemności i związanego z tym niepokoju w minionym roku wzmacniały ograniczenia w przemieszczaniu się, przymus unikania spotkań, wszystkie niedogodności związane z pandemią. Szkoda, że w tym szczególnie trudnym dla różnych osób czasie, muzeum oświecono sztucznym, punktowym światłem. Zmarnowano okazję do kontynuowania dialogu i piękną metaforę, a zamiast światła otrzymaliśmy paternalistyczne „oświecanie”.

\title{
Bibliografia
}

\section{Ariese Csilla E., Wróblewska Magdalena}

2021: Practicing Decoloniality in Museums: A Guide with Global Examples, Amsterdam: Amsterdam University Press.

Lehrer Erica, Sendyka Roma (red.)

2019: Różnicowanie narodowego „my”. Kuratorskie marzenia w Muzeum Etnograficznym w Krakowie, Kraków: Wydawnictwo Uniwersytetu Jagiellońskiego.

\section{Strony internetowe}

\author{
https://etnomuzeum.eu/kolekcje/fotografie-michala-greima \\ https://etnomuzeum.eu/zbiory/obchod-judasza-w-przeworsku \\ https://etnomuzeum.eu/zbiory/rabin-z-belza \\ https://etnomuzeum.eu/zbiory/sceny-zajmujace-malowanka-z-zalipia \\ https://etnomuzeum.eu/zbiory/tefilin-zydow-bucharskich \\ https://krytykapolityczna.pl/kultura/zyd-stosowany-polska-esej-bozeny-keff \\ http://www.widokzzabliska.eu/wystawa/franciszek-skocz-oboz
}

\footnotetext{
${ }^{15}$ Pytania te zadaję w oparciu o publikację Practicing Decoloniality in Museums: A Guide with Global Examples, Csilla E. Ariese, Magdalena Wróblewska, Amsterdam 2021. Dziękuję autorkom książki, organizatorom i uczestnikom warsztatów z 15 lipca 2021 w Muzeum Azji i Pacyfiku za inspirującą dyskusję nad udostępnioną publikacją.
} 
